\title{
Penetration of Dutch Colonial Power Against the Sultanate of Jambi, 1615-1904
}

\author{
Budi Purnomo \\ Department of History Education, Faculty of Education and Teacher Training Program, \\ State University of Jambi, Indonesia
}

DOI: https://doi.org/10.14710/jmsni.v4i1.7498

\begin{abstract}
The arrival of the Dutch in Jambi gave the impression of almost coincidence because Jambi was not familiar and not a large sultanate in Sumatra compared to Aceh. Even Jambi as a relatively small and unimportant kingdom in the 19th century. However, during the colonial era, some penetrations made to the Sultanate of Jambi. This study examines several factors that caused resistance from the rulers and local people of Jambi against the Dutch colonial power. By using a historical method that emphasized on the secondary sources, this study identifies those factors to make penetration. It shows that economic factors in which the Dutch monopoly trading

Received:

March 31, 2020

Revised:

June 16, 2020

Accepted:

June 18, 2020

${ }^{*}$ Corresponding Author:

budi.purnomo@unja.ac.id system is not acceptable to the rulers and local people. It is detrimental and contrary to freedom of trade. Meanwhile, colonial expansion is contrary to the ethical principles they profess. In addition, the failure of the Jambi sultanate had the weakness of their political institutions in facing Dutch colonial penetration. The weakness of their political institutions is influenced by the poor main foundation of the empire and the values of the royal tradition.
\end{abstract}

Keywords: Penetration; Dutch Colonial; Jambi Sultanate.

\section{Introduction}

The arrival of the Dutch who instilled their power through colonialism in Indonesia, at first had caused a reaction of the people's resistance. This resistance emerged in various places and in various forms, some sporadically without organization and in the form of planned and organized social movements. For example, the conflict between native rulers and Vereenidge Oostindische Compagnie (VOC).

The conflict between the indigenous rulers and the VOC which was expanding had various influences on all levels of society, especially those who lived in the sultanate. The solution, is to continue the conflict like Mataram to the death of Sultan Agung or accept an agreement? It is the ruler who first shows the action against the battle whether or not to take it. For powerful kingdoms such as Mataram, Aceh and so on, it might be able to display a challenging, indifferent or resistance action. However, the Jambi Sultanate remains weak.

In 1615, VOC Governor-General Jan Pieters Zoon Coen sent two merchant ships to Jambi Wapen Van Amsterdam and Middleburg under the leadership of Abraham Sterck as Head of VOC Trade Representative (Masjkuri 1985, 16). This mission intends to investigate trade opportunities in Jambi, because the sultanate of Banten refused to deal with the VOC. Finally, on September 15, 1615, the first Dutch trade representative was formed in Jambi and Sterck was replaced by Andries Sourry as Opperkoppman. The dominance of the VOC in Jambi caused unfair competition with the British who came first (Znoj 1998). At that time Jambi was still frequented by Portuguese from Malacca because Jambi was an essential supplier of trade material (Lobato 2012).

Jambi became a selling ground for pepper produced in the Minangkabau hinterland, which the owner brought to Jambi sailed along the Batanghari River. Without pepper from Minangkabau, 
Jambi had nothing to offer on the international market (Schrieke 1956, 53). Even Schrike $(1956,55)$ does not exaggerate saying that Jambi is important by only pepper commodity. Pepper farmers in the Minangkabau mountains brought their produce by boat to Jambi. Usually, 100 to 150 pepper boats come from inland, each carrying about 150 bears of Pepper (Kartodirjo 1997). Chinese merchants play a significant role in this international trade. Jambi Pepper exports are mostly sent to Java (Jepara) and vice versa from Java, Jambi buys rice, salt, silk and textiles (Roelotzs 1962).

In 1904 in Jambi, a new business began to plant cash crops on the land belonging to the village. However, only rubber is giving results and developed rapidly. Along with the planting of cash crops, the colonial government also promoted the export of Jambi forest products in the form of resin, native sap and rattan. However, the development of export trade has no meaning on the economic life of the Jambi people themselves, because the people of Jambi have not been included in the activity. Local people are considered not able to play a role. It was the intermediary traders consisting of Chinese, Europeans, and sons from outside Jambi who made a profit.

The planting of cash crops (rubber) which was initially carried out by prisoners who served the Dwangar Beiders [forced labor] sentence developed rapidly. In 1912, Jambi rubber sold in the Singapore market for $f 3.200$ per ton, so that the Jambi people experienced rapid progress, forest products until 1915 were still the most important export item. If the Chinese, Europeans and sons from outside Jambi have emerged as a capitalist group, the Jambi people themselves (residents) only work as wage workers on large plantations.

This is due to Jambi as the Kingdom still in the formation level (Abdullah 1984). Where the King was in a weak position, while the rich groups were mostly migrants that had a strong influence (Wellan 1926). In its development, it shows that the authority of the King in the interior is very dependent on the cooperation given by the local and regional authorities. While the presence and activities of European traders gradually threatened the first joints of the Kingdom. Every new treaty that was made was not merely reaffirming the contents of the previous agreement but often instead offered things that would weaken the empire in dealing with the colonial government.

Referring to the study of Sultanate Jambi in the modern imperialism history, Locher-Scholten (2003) examines on the implementation of modern imperialism as part of pacification of the outer islands. The study covers the period from 1830 to 1949 including the period where Sultan power ousted. According to her, Jambi can be used a representation of modern imperialism because of the Dutch could do something as called as expansionist. In addition, another focus from Loche-Scholeten (1993) stated that there are two particular rituals represented the power of the Sultan in Jambi, in which probably these rituals was less complex than in Bali. In her study, she underlines that political conflict was expressed in competitive rituals in line with the periodical context. This study also evaluates on the relationship between the Dutch government which had close relation to the Sultanate of Jambi. Therefore, this study reviews on several factors why the Dutch colonial penetrate Jambi and how the local rulers responded on the Dutch imperialism practices? To examine this question, data collection has been conducted through literature studies such as books and journals.

\section{Early History of Jambi Sultanate}

The early history of the Jambi sultanate almost coincided with the rise of Islam, although the exact time was impossible to determine. In the 4th century to the 12 th century, Jambi was known as the centre of the ancient Malay kingdom (Hindu). However, in the 13th century (1275) the Malay kingdom of Jambi was under the influence of the Singasari kingdom, then Majapahit. Under pressure from Majapahit, Adityawarman moved the centre of the Malay kingdom of Jambi in Darmasraya to Pagaruyung, West Sumatra. The Kingdom of Malay kingdom of Jambi in Darmasraya was handed over to his daughter named Puteri Selaras (Selaro) Pinang Masak, who later married a Turkish (Bocrs 1840, 372).

The decline of Majapahit power in the 14th century caused the control of the Malacca Strait to be reduced. This opportunity was used by the Selaras Pinang Masak daughter to move the centre of her kingdom from Darmasraya to the Muara Jambi area called Ujung Jabung (Masjkuri 1985, 4).

Putri Selaras Pinang Masak then married to Ahmad Salim (Datuk Paduko Berhalo) from Turkey on Tanah Pilih Pesako Betuah (Piagam dan Kisah-kisah Negeri Jambi, 1994, 71-83). Ahmad 
Salim or Ahmad Barus II as known as Datuk Paduko Berhalo. Their Marriage had four children, its Orang Kayo Pingai, Orang Kayo Pedataran, Orang Kayo Gemuk, and Orang Kayo Hitam. Of the four children, Orang Kayo Hitam well known by Jambi society, because he considered beingextremely powerful and have a keris obtained from Majapahit named Siginjai.

The administration of Orang Kayo Hitam was estimated in 1500-1515 (Nota van Bestuur Overgave Resident H. L. C. Petri, 2). The Kingdom of Jambi has the highest institution called the XII Meeting. The XII Meeting consisted of the Inner Trainings Council and the Outside Training Council. The Inner Train Council is led by Pangeran Ratu (Crown Prince), and the Oldest Prince heads the Outer Train Council. Each council consists of 6 people. In the days before the empire, council members were elected from the royal family, namely the palace and bandages (Hariadi et al. 1999, 8).

Orang Kayo Hitam then made a change by taking members of the council from lower nobles, namely Kadipan and Pack, even ordinary people or small people. Pepatih as the royal minister and supreme court to try or decide a case carried out by Prince Ratu. Likewise, Prince Ratu, who controlled the government, was accompanied by princes from the nobles of Bandhan and Kadipan along with the ministers whereas Raja (Sultan) does not interfere much in terms of government. Orang Kayo Hitam also divides the kingdom of Jambi into twelve regions called "Kalbu" (nation, the twelve areas are the VII City and IX City, Petajan, Dara Sobo, Jebus Rajasari, Air Hitam, Awin, Intermediary/ Penagau, Liji (Laji), Mestong, Prinokawan and Pemayung, these areas received individual assignments from the Kingdom of Jambi.

\section{The Arrival of the Dutch Colonial in Jambi}

The arrival of the Dutch to Indonesia caused when Portugal entered the territory of Spain in 1585, then the Dutch people who usually became carriers and suppliers of spices in Europe. Therefore, the Dutch needed a place to take or buy spices directly from Indonesia. Sartono Kartodijo $(1997,330)$, explained that the motives of the arrival of the Dutch were almost the same as those of the Portuguese. The purposes of the arrival of the Portuguese were three religions, elimination and adventure, so the arrival of the Dutch had two motives, namely elimination and adventure. To control shipping and trade with the Europeans, in 1602 the Dutch established a trading called the VOC. With the aim, among others, running the politics of monopolizing the trade of spices in Indonesia. This began to be seen when J. P. Cock became governor-general of the VOC.

The Dutch first arrived in Jambi during the reign of Sultan Abdul Kahar. Sultan Abdul Kahar (1615-1643) was crowned king of Jambi and was the king who held the First Sultan in the Kingdom of Jambi (Jambi History from Period 1773, 23). The Dutch arrived in Jambi with two merchant ships named "Wapen Van Amsterdam" and "Middelburg" under the leadership of Dutch Onder Koopmen (deputy head of trade) Abraham Sterek. The Dutch entered Jambi and received permission from Sultan Abdul Kahar to establish a "Logi", but this logi functioned more like a fortress than the Dutch trading office (Masjkuri 1985, 17). The building was erected in Muara Kumpeh on the edge of the Batanghari River.

As refer to the Locher-Scholten (2019) sultan's administration in Jambi had been happened in 1901 since the colonial government built up strong relations with the Sultan. There was multifaceted field embracing modern imperialism and foreign intervention. Sultan Taha managed to sustain its role until 1945 to 1949 . Thus, according to this study colonialism in Jambi lasted for a century because colonial power felt 'comfortable' occupying and controlling government and the economy.

Since the Dutch Colonial got permission to live in Muara Kumpeh, they often intervened in government affairs, even in the overthrow of the Sultan. They take advantage of any disputes between the Sultan of Jambi with other parties such as with Johor. Even disputes among the palace itself, so that finally the Dutch who determine the course of government. The politics of fighting between the Sultan and the Prince Ratu and other aristocratic parties took place either covertly or openly by capturing the Sultan and throwing him into Batavia or to the Moluccas.

The alliance between the Sultanate of Jambi and Mataram angered the Dutch. GovernorGeneral Antonie Van Diemen, in 1642 tried to win the heart of Sultan Abdul Kahar by giving gifts and warnings so that the Sultan did not get in touch with Mataram. To strengthen the Dutch position 
in Jambi, in 1645 a contract or agreement was signed with Sultan Abdul Jalil and the replacement of Sultan Abdul Kahar, the contents of which were for the benefit of VOC. These colonial actions aroused displeasure, hatred and anger from the rulers and the people of Jambi. The pressure and interference of the Dutch became stronger in the days of Sultan Pangeran Ratu Abdurrahman who ascended the throne to replace Sultan Muhammad Fachrudin who died in 1841 with the title Sultan Abdurrahman Nazarudin and Pangeran Ratu, the son of Sultan Muhammad Fachrudin, Prince Sultan Thaha who was titled Pangeran Ratu Jayadiningrat.

\section{Penetration of Colonial Power}

In 1616, Jambi was seen as the wealthiest sity in Sumatra after Aceh. The Sultan makes a profit of $30-35 \%$ of the pepper sold. In 1670 his fame blew to his immediate neighbours Palembang and Johor. However, in the 1680s, Jambi lost its position as the main pepper port on the East Coast of Sumatra after a clash with Johor followed by internal upheaval (Reid 1993, 99).

Issues related to trade, debt and smuggling create tensions between the Ulu and Ilir regions. The Sultan's family, the morals of small citizens and foreigners, have fallen (Jacobs 2000). Eventually the British left their trading post in Jambi in 1679, but the VOC survived even though its trading partnership made very little profit in 1680 (Znoj 1998).

When the leadership changes, it makes the VOC intervene and become active. In 1688 the Dutch arrested the sultan when he came to the trading post to fulfil the invitation and threw him to Batavia. This Dutch action resulted in the splitting of Jambi into two sultanates upstream and downstream (Volt 1993, 56-165).

The increasing influence of Minang was also a result of immigration that began in the mid17 th century and was part of a massive immigration flow that brought people to south Asia to the coast of the Malacca peninsula. One hundred years later, this trend reached the whole of the Jambi to become Minang Kabau (Scholten 2008, 45). This killed Hilir's fate because from then on, Hulu's superiority was unshakeable. Until the end of the 18th century, the Sultanate of Jambi became the vassal of King Minangkabau in Pagaruyung (Marsden 1966).

Colonial influence began to widen from the scope of trade and then monopolize the business of pepper, cloth and several other commodities which penetrated the control and influence the course of government in the Sultanate of Jambi. The politics of splitting and fighting between the sultanate of Jambi and Prince Ratu and other aristocratic parties took place either in secret or openly by capturing the sultan and throwing him into Batavia or Maluku.

Various forms of the agreement continue to be made by the Dutch to the sultans or sultans who were approved and appointed by the Dutch. This Dutch pressure and intervention grew more influential during the reign of Sultan Abdurahman who ascended the throne to replace Sultan Muhammad Fachrudin who died in 1841 with the title Sultan Abdurrahman Nazaruddin and Prince Ratunya Putra Sultan Muhammad Fachrudin's Prince Sultan Thaha Syaifuddin who had Ratu Jaya Diningrat. When Sultan Abdurrahman Nazaruddin died, Prince Ratu Jaya Diningrat or Raden Sultan Thaha Syaifuddin stated and showed resistance against the Dutch government and did not accept and cancel all agreements made by previous sultans.

\section{The Reaction of the Ruler and the People of Jambi}

The pressure and interference of the Dutch in the running of the government in the Sultanate of Jambi and the monopoly of the pepper, cloth and several other commodities got reactions and resistance from the rulers and people of Jambi. The form of their resistance against the Dutch was no different from the resistance of the Indonesian people, traditionally and sporadically (Marsden 1966). At first, the resistance of the people and the rulers of Jambi was not yet an armed resistance but in the form of a boycott of the sale of agricultural produce. This attitude is the result of people's dissatisfaction with the monopoly trading system that was run by the Dutch.

The local people displeasure ended with the closure of the the VOC's trading office in Muara Kumpeh in 1623. The closing of the VOC's trading office resulted in the Dutch having difficulty establishing trade relations with the population. Because people of Jambi do not want to sell their spices to the VOC. The new Dutch trading office was reopened in 1936 by Hendrick Van Gent. This 
is the second Dutch arrival. To strengthen his position in Jambi, an agreement was made in 1645 with Sultan Abdul Jalil and the replacement of Sultan Abdul Kahar whose contents favoured the VOC. This is the first agreement between the VOC and the Sultan of Jambi.

Dissatisfaction with the Dutch shown in 1698, with the killing of Sybrant Swart, head of the Dutch company office in Muara Kumpeh and his staff. Resistance against the Company was also carried out by Sultan Muhammad Fachruddin who attacked the Dutch post in West Sarolangun. Although finally Sultan Muhammad Fachruddin surrendered and had to sign an agreement prepared by Lieutenant Colonel Nichiel on the Baung River (Rawas) on 4 November 1833 which contained (Masjkuri 1985, 22); (1) The Kingdom of Jambi is under the influence and protection of the Dutch;

(2) The Dutch has the right to place its personnel in places that are considered essential and strategic.

The agreement was deemed incomplete so on 21 April 1835 it was renewed by the Palembang Resident as a representative of the Dutch government whose contents (Masjkuri 1985, 23): (1) The Dutch government has the right to collect excise duty on imported and exported goods; (2) The Dutch government has the right to monopolize the sale of salt; (3) The Dutch government will not take care of other excise duties; (4) The Dutch government will not interfere with governmental affairs and customs, except in the case of excise management which is the Dutch's right; (5) Sultan and Pangeran Ratu get money of $f 8.600$ every year.

Dutch penetration became stronger during the days of Sultan Abdurrahman Nazaruddin and Pangeran Ratu Jayadiningrat (Pangeran Thaha). Prince Thaha was aware of the Dutch pressures on the Sultan as a Dutch intervention in the government and life of the Jambi people. This prompted Prince Thaha without the knowledge of his uncle to enter into an arms purchase contract with an American trade mission in Singapore. These actions were known by the Dutch and the Dutch authorities in Batavia. The Dutch then sent the Assistant Resident of Palembang resident to Jambi for inspection at Muara Kumpeh. It came to the Tanah Select palace to commemorate the Sultan to abide by the previous agreement.

The agreements that had been forced on the Sultanate of Jambi, in essence, wanted to put Jambi under Dutch rule. The people of Jambi certainly reject all forms of extortion and occupation. When Prince Thaha, the son of Sultan Muhammad Fachruddin was appointed as Sultan, he did not want to acknowledge all forms of oppression and agreements that had been made by the Dutch Colonial. Even Sultan Thaha did not want to negotiate or enter into a new agreement with the Dutch.

\section{The Weakness of Political Institution}

The failure of the Jambi sultanate in dealing with Dutch political and trade power was primarily due to the weakness of its political institutions. The making of any treaties as long as they were profitable had become a VOC (Dutch East Indies) deception until the abolition of the sultanate of Jambi in the early twentieth century (Abdullah 1984).

The first treaty was signed in 1630, which was expressly made to oppose the Portuguese presence. In 1634 the VOC urged Jambi to approve the contract, which banned Chinese from trading in Jambi because Chinese traders played an essential role in pepper exports. Sources from the seventeenth century mentioned several names of Chinese intermediary traders, including "Little Yapon" who was famous as a rich man of Sirri Jaunty and he was accepted, in the elite society of Jambi, which eventually caused the envy of Dutch traders. Even in 1634, these Chinese traders agreed, the contents of which were if the Dutch did not want to pay export duties for pepper, then Chinese traders would come with six or seven junks. This means that all Jambi pepper will be bought at once. As a result, Dutch ships no longer came to take pepper to Jambi but instead withdrew Jambi ships to bring their ladders to Batavia.

Another indication was that in 1690 the head of the Dutch Trade Office was killed because of betrayal from the local on behalf of the sultan. The VOC demanded the Sultan's responsibility for the killing, so the Dutch immediately arrested him in the Office and then sent him to Batavia and then banished to Banda. Instead of Prince Ratu, the rightful person to inherit the Crown of the Sultanate, but the VOC named the exiled Sultan's son as the new ruler. The disappointed Pangeran Ratu withdrew to the interior of Muara Tebo, and then he has crowned the new ruler. The Sultan who had the Dutch support established a palace in Tanah Select (old Jambi) and Prince Ratu who 
fled to Muara Tebo using the title Sultan Sri Maharaja Batu and supported by migrants from Minangkabau and received recognition from the Minangkabau king in Pagaruyung.

In 1724, the VOC Trading office in Jambi was vacated, the VOC strengthened its position in Palembang. The VOC planned to establish a new trade representative in 1791, but it was never carried out. Only in 1838 did the Sultanate of Jambi have a direct relationship with the Dutch. When in 1833 the Sultan of Jambi Muhammad Fachruddin asked the Dutch East Indies government to help crush the entrenched pirates at the Batanghari River Estuary and control the Rawas region which was under the rule of the Palembang Sultanate. This mission was successful, but in return, the Dutch forced Sultan Muhammad Fachruddin to sign an agreement known as the Sungai Baung Hamlet 1835 agreement. It contained that Jambi was controlled and protected by the Dutch and the Dutch had the right to establish power within the Jambi area where necessary (Sudarto 1997).

This agreement was deemed insufficient and was further refined on April 21, 1835, signed by Sultan Muhammad Fachruddin, Prince Ratu Abdurrahman Kartaningrat and some of the Jambi Nobles whose contents were as follows: (l) The Dutch government collected excise from all income and expenditure of goods; (2) The Dutch government has the right to monopolize the sale of salt; (3) the Dutch government does not collect another excise; (4) the Dutch government will not interfere in domestic state administration matters and does not interfere with the customs of the Jambi Sultanate except in the case of the management of excise that is entitled to be collected by the Dutch; (5) The Sultan and Prince Ratu were given an annual fee of $f 8.000$.

The first stage of Jambi's relationship with the Dutch that lasted for a century until entering the beginning of the second phase was seen by the Jambi Sultanate that did nothing to force the VOC to close its trade Representative Office or expel the VOC from Bumi Jambi Sembilan Lurah. This shows not only the Sultan's deep involvement in the ever-changing system of alliances but also shows the structure of his weaknesses and failures. The sultan only controlled one area in the government sector, while he was ruling in the government sector. Therefore, the sultan did not have absolute autonomy.

\section{Structural Weaknesses}

In the seventeenth century, Jambi was a kingdom which was very vulnerable to its neighbours. Therefore, Jambi must bind itself with its ever-changing allies, the Kingdom around it. If necessary Jambi must end or submit to more influential empires. Unlike Aceh and Mataram in the seventeenth century, they were able to stand or stand up structurally the authority of their empire (Reid 1977, 391-420). While Jambi was unable to escape its structural weaknesses, the Jambi Sultanate must face a tendency to be left behind continuously in its government structure.

This can be seen from the sultanate of Jambi itself, which consists of six political traditions, each of which has different interests, political arrangements and powers. The relationship between them and the sultan also differed, as the XII people who settled along the Batanghari river were directly under the sultan's control. Still, the Batin people who were considered as the earliest people came to Jambi and occupied the area along Batang Anai and Muara Tembesi were only a colony from the sultanate of Jambi. Although the Batin was given leeway to govern their territory, they were subject to the obligation to pay Jajah money in recognition of the sultan's power through Jenang as the sultan's representative (Tideman without year, 57-80). Therefore, in this case, the sultan must take into account not only his relationship with different political arrangements but also the threat of competition in the empire against the integrity of the empire. Therefore every sultan must be accompanied by a queen prince, the son of the previous sultan.

The queen's prince ran the sultanate government accompanied by the princes of the bandages and Kadipan nobles along with the ministers. The Minister is a member of the XII meeting or Pepatih Dalam council and the Pepatih Luar council. The unity of this institution is called the royal board. Pepatih in charge of running government affairs, development, defence and security, economy, and social culture of the XII nation or the federation of royal people. While Pepatih outside runs the government of the countries, villages and shoreline throughout Batanghari. Customary leaders such as villages, villages, and so on contain different titles, such as Rio, Rio Depati, Rio Pamuncak, Temanggung, Depati, Kedemang, Lurah, Penghulu, Ngebi and Mangku. They run affairs related to the village or village (Bocrs 1846). 
The most crucial customary title "Susuhunan" is given to the oldest members of the palace. Susuhunan has the authority to provide advice on appointing ministers, reprimanding and providing information to the Sultan above the clean line, rejecting or refuting a regulation or action that is not following "Adat Bersendi Syarak, Syarak Bersendi Kitabullah". The Sultan also appointed people from the royal family to be the coordinators of the government in a particular area with economic duties and traditional supervision, known as "Jenang". The task of Jenang as an intermediary in "Serah Turun and Jajah Naik" means that the Sultan gives the people work tools and necessities of life (hand down) and receives a few percents of the work (jajah) every year or two.

\section{Uphold the Sultanate Authority}

In 1855 after Sultan Thaha Syaifuddin took the throne, he tried to reestablish the authority of the Jambi Sultanate by not recognizing the agreement signed by his father (Sultan Fachruddin) and refusing to discuss it with the Dutch and refusing to meet with the delegation of the Dutch Indies Government who came to deliver a letter from the Governor-General. In 1857 Prince Ratu read a letter from Sultan Thaha Syaifuddin to the Turkish Representative in Singapore. Sultan Thaha Syaifuddin asked the Sultan of Turkey, who was recognized as the Caliph of the Islamic World to announce a ban on interference in Jambi's internal affairs for all powers in the region (Abdullah 1984).

Sultan Thaha's reaction triggered a conflict, so the Dutch sent an ultimatum that Sultan Thaha ignored. Finally, on September 25, 1858, the Dutch declared that they did not recognize the Sultanate of Sultan Thaha Syaifuddin and assumed that the Sultan had been demoted from his throne. Then there was an attack on Jambi in November 1858 and the removal of Sultan Thaha from his throne. Sultan Thaha, Pangeran Ratu Kartaningrat and several other royal authorities retreated to Muara Tembesi intending to arrange tactics and strategies of resistance (Locher-Scholten 2003).

The Dutch named Sultan Thaha's uncle, named Peramudjaja, as the Sultan of Jambi (the new Sultan) with the title Sultan Ratu Achmad Nazaruddin (1858-1881). Prince Ratu Kartaningrat's position was restored. At that time Sultan Achmad Nazaruddin, Pangeran Ratu Kartaningrat and other royal authorities had to sign an agreement with the Dutch. The deal reaffirms the validity of several previous agreements and Jambi and some of the areas it has conquered are part of the Dutch East Indies. In 1858 this agreement was renewed and added to, covering both economic and political rights of both parties. If the Sultan died, the Prince Ratu could temporarily replace his position in control of the government. The coronation of Prince Ratu ascended to the throne to become a Sultan, and the appointment of a new Prince Ratu had to be approved by the Dutch. Such methods are often used for each coronation of the Sultan and the selection of a new Prince Ratu. While from the Dutch, the royal family will get annual assistance and protection.

The departure of Sultan Thaha to Muara Tembesi remained respected and gained loyalty from the aristocracy, sons of the king and the people of Jambi. For this reason, Sultan Thaha, who was in exile, remained a force to be reckoned with by the Dutch. Those who were loyal followers of Sultan Thaha in the interior continued to carry out sporadic armed attacks on army posts and representative offices of the Dutch East Indies. During the war, Sultan Thaha received help from the local in the interior (Jacub and Soedarmanto 1979). The Dutch army used complete weapons, such as pistols, guns and cannons. While the Sultan Thaha's army only had simple weapons, such as a dagger, spear, axe, hardwood and arrows. As a result, the Jambi army was defeated everywhere, and many were killed.

The existence of a Sultanate with these two Sultans seems to be an unacceptable factor for the king's son. To end the situation, various political actions were carried out, among others by appointing the son of Sultan Thaha named Prince Anom Kusumo Yudo who was four years old to become the new Prince Ratu. This incident hugely disappointed the son of Sultan Muhammad Maniluddin who should go according to royal tradition, he had to become Prince Ratu. These politics turned out to be successful, with the surrender of the royal heritage of the Keris Siginjai which became a symbol of the validity of the Sultan of Sultan Thaha to the new Sultan and his son (the new Prince Ratu) Sultan Thaha handed over the Keris Singa Merjaya.

In 1880, supporters of Sultan Thaha aggressively attacked Dutch defence posts. The emergence of the amok incident in May 1885 in the Dutch community village in Jambi. Two Dutchmen and a native were killed, and many Europeans were wounded by Raden Anom, a nobleman who in 1880 
collected weapons for Sultan Thaha in exile. In 1889, Sultan Thaha's brother, Pangeran Dipa Negara established a stronghold at Muara Tabir. Prince Kusin also built the same fortress at Muara Sekanis. In these strongholds, they collected excise from passing merchants and announced that they would not allow Europeans to set foot in Jambi. In the early 1900s, the atmosphere was exacerbated by Minang migrants who incited the local community to fight the Dutch.

This increasingly precarious atmosphere encouraged the Dutch with various efforts to capture Sultan Thaha immediately. In early 1903 due to his helplessness, Pangeran Ratu (Putra Sultan Thaha) gave his land of authority to the Dutch who stretched from Muara Tebo to around Muara Tembesi. Likewise, as a sign of his loyalty to the Dutch, he handed the Mera Singa Meraka Pusaka Crown Prince crown to the Palembang Resident. It was complete when he handed over the Siginjai kris by Prince Prabu Negara, son of Sultan Maniluddin and Sultan Thaha's son-in-law, to the Resident. Politically, the Sultanate of Jambi is now under the authority of the Dutch East Indies government. Sultan Thaha, who remains a respected figure, experienced an armed incident. Precisely at Betung Bedaro on 21 April 1904 Sultan Thaha Syaifuddin was killed in his obsession with expelling the Dutch Colonial from the Jambi area. Then followed by the death of Prince Dipa Negara, Raden Mat Taher the highest Commander in 1907 in Muaro Jambi. In essence, the Dutch were only able to arrange a colonial government in the Jambi area after the death of Sultan Thaha Syarifuddin (1904) and the surrender of Prince Ratu by making Jambi and Kerinci in one Gewest under the orders of the Resident named O.L. Relfrich as the first Resident (Syahbuddin 1954).

\section{Political Change in Jambi}

In the field of government, the Dutch made a total overhaul of the government structure in Jambi. The sultanate was abolished, as was the position of the regional head which was once held by the sons of the king (aristocrats). As the highest colonial government official in Jambi in 1901, an Assistant Resident was appointed who was responsible to the Resident in Palembang.

In 1906, Jambi only became a Residency apart from the Palembang Resident Jambi assisted by six Controleur, namely Controleur for Jambi, Muaro Tembesi, Sarolangun, Bangko, Muara Tebo and Muara Bungo. The Controller position was the lowest in the hierarchy of the colonial administration held by the Dutch. Therefore, the relationship of the Controleur with the hamlet and village government and the people of Jambi is challenging to achieve. Finally, the Dutch introduced the position of demang held by Bumiputera officials who had received a Western education. Because there are no modern-day Jambi people, the demang position is held by people from outside Jambi, namely Minangkabau and Palembang.

The Dutch also strengthened the Police Stations reign, where the king's son (aristocrats) who had once helped Sultan Thaha were exiled outside Jambi and those who were considered harmless were ordered to live in the city of Jambi. If they travel outside the city of Jambi, the Dutch government must permit. Their movements are always monitored, and their fellow contacts are minimal so that their relations with the people are cut off.

The Police State government was beneficial, many rebellions failed, even before it began because the plan was known to the Dutch through its spies. The extensive treatment of the king's sons (nobles) had a psychological impact, not only on the king's sons (nobles) themselves but also the people of Jambi. demang plays a vital role in this matter since 1901 has been tasked with accompanying the Dutch military expedition to the interior areas. In fact, in 1904 demang had led a police patrol, because of that the people of Jambi did not like the existence of demang.

After the war ended, demang was entrusted with administrative duties as an intermediary among others: supervising school absences, assisting health workers in the effort to become infected, and managing infectious diseases, investigating criminal cases and making arrests, supervising compulsory labour, planting rice and so on. Because most of the Dutch controleur did not master the local customs and language and the position of the controleur in a place not long ago, then demang became a small controleur who helped the Dutch controleur task.

Although the Dutch did not make changes to the village administration, the Dutch formed an administrative unit called the Gouvernements District which consisted of one or several hamlets. The Dutch also carried out a solution to the unity of the legal community based on genealogical relations. 
For example, the Jebusese were split into Jebus and Dendang, and the Maro Sebo became Maro Sebo Hulu, Maro Sebo Hilir and Maro Sebo Tengah. In 1912, 83 existing districts were simplified into 25 regions and were given the rank of demang. Because they do not get the demang of the Jambi people themselves, the demang from outside Jambi is still maintained. This caused dissatisfaction with the people of Jambi.

\section{Conclusion}

The attitude and actions of the Dutch colonials who came to Jambi with their trade monopoly system and the existence of an effort to instil power in Jambi got a reaction from the Jambi authorities and people. Three things cause a reaction or resistance from the police and the people of Jambi, namely; economic, religious and governance factors. The failure of the Jambi Sultanate to deal with political power and Dutch colonial trade was partly due to the weakness of its political institutions. This was said by Sourry, an Opperkoopman in Jambi that the king has very little authority in the eyes of the people. The power mechanism was fragile. The weakness of this political institution is one of the factors causing the sinking of the Sultanate of Jambi in the colonial grip which had an impact on the main points of the kingdom, the loss of imperial authority and the destruction of the values of royal traditions. The imposition of Sultan Thaha Syaifuddin to step down from his Throne and the coronation of Sultan Thaha's uncle as the Sultan and not the queen's ruler who had the right to ascend the Throne was a proof of destroying the continuity of royal traditions and also gave birth to uncertainty in the course of government. This practice was also applied by the Dutch in Java, especially in Mataram and other places in the Indonesia archipelago.

Sultan Thaha Syaifuddin and his followers tried to reestablish the authority of the empire and the values of the royal tradition. However, they had to die on the battlefield by carrying out their obsession, driving out the invaders from the land of Jambi Sembilan Lurah.

\section{References}

Abdullah, T. 1984, Reaksi terhadap Perluasan Kuasa Kolonial. Jakarta: Prisma.

Badan Pelaksana Pendidikan Museum Provinsi Jambi, Sejarah Jambi dari masa ke masa Jambi: 1773. Bocrs, J. W. 1840. Oud Volksgebrulk In Het Rijk Van Jambi, Tijdsleruif Van Neederlands Indie.

Bocrs, J. W. 1846. Legluden Van Djambi, Tijdschrift Van Neederlands Indie.

Hariadi, Ujang. 1998. Keris Siginjai Dalam Legenda dan Sejarah Jambi, Kolonial Provinsi Jambi Proses Pembentukan Pemerintahan Jambi. Jambi: Dinas Pendidikan dan Kebudayaan.

Jacub, J., and Soedarmanto.1979. Sejarah Nasional Indonesia. Jakarta: Balai Pustaka.

Kartodirjo, Sartono. 1977. Sejarah Nasional Indonesia. Jakarta: Balai Pustaka

Lobato, Manuel. 2012. "Melaka is like a cropping field" Trade Management in the Strait of Melaka during the Sultanate and the Portuguese Period." Journal of Asian History 46 (2): 225-251. https://www.jstor.org/stable/41933622

Locher-Scholten, Elsbeth. 1993. "Rivals and Rituals in Jambi, South Sumatra (1858-1901)." Modern Asian Studies 27, no. 3 (July), 573-591. https://www.jstor.org/stable/312962

Locher-Scholten, Elsbeth. 2003 Sumatran Sultanate and Colonial State. Jambi and the Rise of Dutch Imperialism, 1830-1907. Ithaca and New York: Cornell University.

Locher-Scholten, Elsbeth. 2008. Bangkitnya Imperialisme. Translated by Yusi Avianto Pareanom and Noor Cholis. KITLV: Jakarta.

Marsden, W. 1966. The History of Sumatera, Containing in Account of the Goverment, Law, Customs And Namners of the Native Jilabitaut and a Relation of the Ancient Palitical Rare of that Island, third edition 3. Kuala Lumpur: Longman.

Masjkuri. 1985. Sultan Thaha Syarifuddin. Jakarta: Direktorat Sejarah dan Nilai Tradisional Depdikbud.

Nota van Bestuur Overgave Resident H. L. C. Petri.

Piagam dan Kisah-kisah Negeri Jambi. 1994.

Reid, Anthony. 1977."Trade and State Power in the Sixteenth and Seventeenth Century Southeast Asia." Proceedings Seventh IAHA Conference (Bangkok, 22-26 August) 
Roelotzs, Meilink. 1962. Asian Trade and Eropean Influece. Den Haag: Martinus Nijhof.

Schrieke, B. 1956. Indonesia Sosiological Studies Vol. I. Den Haag : Van Hoeve

Sudarto. 1997. Kronologis Historis Perjuangan Sultan Thaha Syaifuddin di Jambi (1855-1940). Pusat Studi Seni dan Budaya Lembaga Penelitian Universitas Jambi, Jambi.

Syahbuddin, R., 1954. Sejarah Perjuangan Jambi dari Abad ke Abad. Palembang: Balai Pustaka.

Tideman. J., P. F. L. Sigar. Without year. Djambi. Amsterdam: Koninklijke Vereeniging Kolonial Institut.

Volt, R.C. 1993. Center Jambi, Deroliant Prince : The VOC and the Tigh Tear of Diplomacy in The Valay Wood, 1740-1800. Laiden: Kitcu Press.

Znoj, Heinzpeter. "Sons versus Nephews: A Highland Jambi Alliance at War with the British East India Company, ca. 1800.” Indonesia no. 65 (April), 97-121. http://www.jstor.com/stable 13351406 